\title{
Foreign Trade Policy in Realisation of Economic and Political Interests
}

\author{
Zdzisław W. Puślecki ${ }^{1}$ \\ ${ }^{1}$ Department of International Economics, Faculty of Political Science and Journalism, Adam Mickiewicz University, \\ Poznań, Poland. \\ Correspondence: Prof. Dr. Zdzisław W. Puślecki, Department of International Economics, Faculty of Political Science \\ and Journalism, Adam Mickiewicz University, ul. Umultowska 89A, 61-614 Poznań, Poland.
}

\author{
Received: August 6, 2015 \\ Accepted: August 20, 2015 \\ Available online: August 28, 2015 \\ doi:10.11114/afa.v2i1.1058 \\ URL: http://dx.doi.org/10.11114/afa.v2i1.1058
}

\begin{abstract}
In this research work, author focuses on the analysis of the theory of foreign trade policy and important political and economic interests. Realistic point is important trends in the trade regime. The decisions taken by the representatives of the governments participating in the World Trade Organisation (WTO) are, to a significant degree, influenced by various lobbies, such as organisations and unions of food producers or other non-governmental organisations, including trade unions. The main objective of the research task is to give a comprehensive analysis of the international trade policy. The particularly main concern the political economy models of foreign trade policy, protectionistic pressures in different political system, the level of protectionistic pressures, food producer pressures, international trade liberalization and environmental protection, bilateral tendencies in the foreign trade policy. It must be emphasis that on a theoretical level, understanding the choice of trade policies between liberalizm and protectionisme is very important. Despite the undeniable benefits of the multilateral WTO forum for trade liberalisation, the rapid increase of North-South bilateral and multilateral Free Trade Areas (FTAs) begs a systematic explanation for why some forums are prioritized relative to others.
\end{abstract}

Keywords: foreign trade policy, economic interests, protectionistic pressures, level of protectionistic pressures, bilateral tendencies

\section{Introduction}

Different positions of the member states of the World Trade Organization (WTO) especially developed and developing countries and also USA, the European Union and Japan representatives were observed during the Doha Round of trade negotiations under the WTO. The problems of agriculture protection in the developed countries for example in European Union and USA and also in the developing countries, were becoming a serious obstacle during the negotiations. The decisions taken by the representatives of the governments participating in the World Trade Organisation (WTO) are, to a significant degree, influenced by various lobbies, such as organisations and unions of food producers or other non-governmental organisations, including trade unions. The problems of mutual relations between the representatives of governments and those non-governmental organisations which influence on multilateral trade negotiations conducted on the forum of WTO are also the subject of the analysis in the undertaken research program. Despite the undeniable benefits of the multilateral WTO forum for trade liberalisation, the rapid increase of North-South bilateral and multilateral Free Trade Areas (FTAs) begs a systematic explanation for why some forums are prioritized relative to others. The main aim of the article is the presentation of the theory of foreign trade policy and important political and economic interests. The article presents the political economy model of the foreign trade policy, protectionistic pressures in different political systems, the level of protectionist pressures, food producers pressures, international trade liberalisation and environmental protection, the bilateral tendencies in the contemporary foreign trade policy. The main objective of the research task is to give a comprehensive analysis of the theory of foreign trade policy in realisation of the important political and economic interests.

\section{Method}

Paper prepared in the framework of the Grant OPUS, National Centre of Science -NCS, $\mathrm{Nr}$ UMO-2013/11/B/HS5/03572. The analyzed problems were solved with the use of qualitative research method. The main research method applied in this analysis, was a method of scientific study used for splitting the whole (of individual items, their sets, phenomena) by means of logical abstraction. It was also used the analogy (comparative) method, which 
consists in finding similarities and differences between the items under study, the documentation method. It were applied the descriptive method. Additionally, it were used the methods of deductive and inductive forecasting. For the presentation of the problem the level of protectionistic pressures was adapted the mathematical model.

\section{Results}

What indicates the importance and innovativeness of the research is the presentation of the new protectionistic tendencies and inclination to bilateralizm and regionalizm in the contemporary foreign trade policy. First of all it must underline that in the new theoretical terms in the demand for trade policy very important is factor specificity. Some factors are stuck in their present uses; therefore, factor returns are not equalized throughout a region's economy, but are industry specific. Trade policy coalitions should form along the lines of exporting versus import-competing industries. It must be emphasis that on a theoretical level, understanding the choice of trade policies between liberalizm and protectionisme is very important.

Question is how can we recognise the type of power, the type of rule? First of all, we should investigate what level of resources a given government is going to achieve. If an authoritarian government is more or less corrupted than a democratic one, it will be creating the income, to a bigger or lesser degree, through protectionism. It will also appropriate some part of that income. Secondly, a given type of government may remain under the influence of different pressure groups. If an authoritarian government is trying, to some extent, to subordinate special pressure groups including the regulated labour sector, it will be, to some extent, generating incomes through protection and it will be turning over some part of them to those special pressure groups.

It should be pointed out that there exists a close relation between democracy and an economic growth, There are well known examples of open societies that stimulate the economic growth. This is true mainly in case of highly developed and strongly urbanised countries. In the countries with a developed democracy, the pressure groups have a bigger opportunity for acting. The research shows that the presence of trade unions helps to accelerate the economic reforms. The benefits resulting from liberalisation of the international trade are bigger when the trade unions exist in the sector of the economy under protection. The growth of import abilities leads to the decrease of wage pressures, and when the trade unions agree to that, such a situation allows for a better allocation of labour force in the economy. This is true both in the case of active and passive trade unions, although the effects are better in case of active trade unions.

The growing interdependence and the decline of USA trade hegemony have led to increased competitiveness and greater temptations to resort to strategic trade policy. Trade policy takes on additional importance in economic battle of "the valiant liberal reformers, fighting against self-dealing rent seekers profiting from inconsistencies of the transition economy". Many of the clientelist policies that shelter rent seekers are impossible to maintain in the face of competition in the international economy. On the other hand, high tariff walls, export licensing, and artificial exchange rates provide numerous sources of rents for business people who are trying to promote their own loyalties.

The reduction or the elimination of trade restrictions stimulates significantly the growth of the world trade exchange, while the foreign trade, in turn, is an important factor of the economic growth of individual countries. However it should be stressed that free trade in itself is not responsible for economic growth, but more significant are the determining macroeconomic stability and increasing investment.

Reaching the effective agreements on the international trade liberalisation and on environmental protection in the light of sustainable development is considered to be both very difficult and very delicate question. The problems of environmental protection have become most important issues. Therefore, it is evident that the international market has to take them into account. In the context of the sustainable development, the key problem is to make a proper choice: is the introduction of restrictions on international trade the best solution, or will the benefits from environmental protection (as applied by a multilateral trade system) be higher than the costs?

It is necessary also to emphasis that if the rules of international trade are clear - and if they are perceived to be supportive of important environmental values - then their legitimacy will be much greater. Over the long term, public support for the WTO depends on a perception that it is balanced and fair. Efforts to address the issues identified above could greatly enhance the WTO's reputation. Competing trade and environmental principles could best be balanced through creation of an interpretive statement that focuses on how the "exceptions" spelled out in Article XX would be implemented, rather than through full-blown renegotiation of the environmental elements of the trading system.

At one end, a multilateral forum with near universal membership offers maximization of gains from trade and reduced transaction costs. However, a single state cannot expect to have much control over trade partners or liberalization agendas at the multilateral level. At the other end, a bilateral FTA often yields very small gains from trade and usually increases transaction costs by producing idiosyncratic sets of rules. But at the same time, a large state can acquire a high level of control in terms of partners, issues and agenda selection, and sectoral exclusions or inclusions based on domestic political 
needs. One can contend that industrialized of aggregate economic gains in the interest of national welfare (largest in multilateral forums) or seeking control over rules in line with political interests (greatest in bilateral forums).

The increase regionalisation of economic cooperation and the bilateral agreements between particular countries is a kind of behaviour with which many countries react to the challenges posed by the world economic crisis. Strengthening of already existing regional groups like European Union, creating new agreements and new trade blocks causes a specific "fragmentarisation" of the global economy. The increase of economic ties between such groups and countries is the effect of economic crisis.

The new trends concern also the common trade policy of the European Union. This has been reflected in the growth of bilateral agreements, for example, between the European Union and ASEAN countries and in the proposals for creating a transatlantic free trade area between the European Union and the United States of America. In such a situation occurs to the liberalisation of trade within the framework of bilateral agreements and in a lesser extent in the framework of the multilateral system of international trade of the WTO.

\section{Discussion}

\section{1 Political Economy Model of Foreign Trade Policy}

Traditionally, political economy models of trade policy have tendend to focus on the demand for protection, with factor endowments driving political reactions to exposure to international trade. Such model simply assumed that adversely affected economic agents would organize to seek protection, which would be afforded to them by their elected representatives in the political system. The supply side for trade policy was either ignored or underspecified in most model (Thies and Porche, 2007).

In the new model of the foreign trade policy theory interesting are the reviews of Alt et al. (1996) and Nelson (1988) about the demand for trade policy in terms of the theoretical importance of factor specificity (Alt, Frieden, Gilligan, Rodrik and Rogowski, 1996; Nelson, 1988). Factor specificity refers to the ease with which factors (land, labor, and capital) can move from one sector to another in an economy. The two dominant approaches to explaining the demand side of trade policy used radically differeent assumptions about the specificity of factors. The Heckscher-Ohlin model, used by Rogowski (1989) in his seminal contribution "Commers and Coalitions", assumes very low-factor specificity (Rogowski, 1989). The low specificity of factors means that factor returns are equalized throughout a region's economy. Producers should export goods that intensively use their abundant factors and import goods that intensively use their scarce factors, with the result that owners of abundant factors will favor free trade and owners of scarce factors will favor protectionisme. Trade policy coalitions will therefore be organized along factor or class lines. On the other hand, the Ricardo-Viner assumes that some factors are stuck in their present uses; therefore, factor returns are not equalized throughout a region's economy, but are industry specific. Trade policy coalitions should form along the lines of exporting versus import-competing industries.

Neither of these models explains how preferences over trade policies are actually translated into political action (Alt, Frieden, Gilligan, Rodrik and Rogowski, 1996). In a discussion of the endogenous tariff literature, Nelson (1988) notes that the mobility costs of the specific-factors model may be a result of productivity differentials, labor union activity, or individual preferences for membership in a given geografic area, industry, or firm (i.e., some form of solidarity) (Nelson, 1988). In all of these cases, one can derive a link to preferences for tariff policy, "but without additional information on why the specific-factor model is chosen, it does not tell us much about political organisation".

Alt et al. (1996) suggest that one can begin to understand this process by assuming that rational individuals make cost/benefit calculations (Alt, Frieden, Gilligan, Rodrik and Rogowski, 1996). The Heckscher-Ohlin and Ricardo-Viner models tell us the benefits that individuals hope to recive, but the costs of collective action also intervene as they organize to achive those benefits in the political system. Olson (1985) argued that small groups with specialized interests are easier to organize and more effective in securing economic rents than large groups with diffuse interests (Olson, 1985). Small groups are better able to control free riders than large groups, and groups with specific or homogenous interests can more easily coordinate and target their activities than groups with diffuse or heterogenous interests. This approach is thought to explain the success of agricultural producer groups in developed countries in organizing for protection as well as the inability of agricultural producer group to organize in developing countries (Anderson, 1995; Coleman, 1998; Olson, 1985; Olson, 1986; Sheingate, 2001).

However, Nelson (1988) points out that we should not assume that organized interests will be equally responsive to all issues (Nelson, 1988). Institutionalized interaction among actors may help to explain systematic patterns of action, espacially as institutions created for specific historical purposes may outlive those purposes. Alt et al. (1996) suggest that if a particular group has paid the fixed costs of establishing collective action and developed well-worn channels of acces to public officials, it may defend its trade policy preferences even when the stakes are low because the marginal costs of action are low (Alt, Frieden,Gilligan, Rodrik and Rogowski, 1996). It may be the case that "a much more affected but inchoate group does nothing because the start-up costs of organization are too daunting". Past strength of an organization 
should therefore be an important intervening variable predicting group action on trade policy. Further, as Nelson (1988) argues, once these institutions exist, supply-side interventions may also affect their usefulness as some are deemed legitimate or illegitimate aggregators of interest (Nelson, 1988). Thus, we must examine the way in which economic institutions and political institutions interact. Most economic models simply assume that a model of the economy is a model of the demand side for trade policy, but Nelson (1988) suggests that we must elaborate the mechanismes by which demand is articulated to the suppliers of trade policy (Nelson, 1988). For a good overwiew of this argument, especially as it pertains to agriculture (Thies and Porche, 2007).

If the political systems rewards small sectoral groups, than individuals will not pay the costs of organizing large intersectoral coalitions. If the political system rewards large mass movements (i.e., majoritarianism), than individuals will have to pay the costs of organizing large intersectoral coalitions in order to achive any benefits. Collective action costs and political institutions are interactive with factor specifity. They suggest that Rogowski's (1989) Heckscher-Ohlin framework requires low factor specifity, low collective action costs, and domestic political institutions that favor mass movements (Rogowski, 1989). The Ricardo-Viner framework used by the endogenous tariff literature requires that factors are specific, collection action costs are high, and institutions are less majoritarian, with changes in any of these three variables also affecting the typ of coalitions that form.

In the state as a rational dictator model, the state may be seen as either pursuing "good government" goals along a social welfare function or intervening in the economy for their own self- interested model of the state views politicians as offering preferential trade policy to economic actors in exchange for political support (Magee, Brock, Young, 1989), (Grossman and Helpman, 1984). On the other hand, pluralist theory typically views the state as a neutral aggregator of demands from groups in society. The supply of trade policy is then determined by the balance of power on any given issue. The supply side of trade policy is relatively undeveloped theoretically, and yet a crucial part of the equation. A variety of different characteristics of the political system are posited to affect the supply of trade protectionism, such as politicians incentives to cultivate personal votes, the size of electoral districts, party fragmentation, federalism, presidential versus parliamentary systems, and so on (Nielson, 2003; Rodrik, 1995; Rogowski, 1987; Rogowski, 1987).

On a theoretical level, understanding the choice of trade policies in countries is very important. A survey of economists in 1984 suggested that one of the few things they agreed on was that, under most conditions, tariffs, and quotas reduce the general welfare (Frey, 1984). The stubbornness of protectionism in the face of international and academic pressure against it has led economists to seek explanations. These explanations range from the simple ignorance of politicians to arguments about the rationality of protection for "infant industries" and "optimal tariff levels" in developing states. Faced eith this frustrating question, scholars have increasingly turned to political answers in order to explain the choice of what would seem to be an "irrational" policy (Frey, 1984; Nau, 1989; Nelson, 1988).

\section{2 Protectionistic Pressures in Different Political Systems}

It is important to indicate, that the role of trade unions in different political systems may be, to a high degree, different. In authoritarian systems it is, as a rule, smaller than in democratic systems. It would seem that if protectionistic pressure on the part of trade unions is weaker, the situation for economic growth is much better. Following that line of reasoning we could come to conclusion that the authoritarian system is better for the effectiveness of the labour market. The examples of Chile, South Korea, Singapore and Turkey from the seventies and early eighties could confirm that point of view. In many cases during those two decades the authoritarian regimes persecuted trade unions and put restrictions on basic labour rights. During that period of oppression, South Korea, Singapore and Turkey experienced a spectacular growth in the sector of processing industry and in the growth of demand for labour. Growing profits and the demand for labour in a processing industry, caused a general growth of prosperity of the employed. Although similar results were not noted immediately during the authoritarian phase of development in Chile, a number of observers express the opinion that the reforms introduced at that time helped to reorganise Chilean economy in the nineties. The application of democratic rules, on the other hand, may lead to lower productivity of labour force. In a number of years different democracies had to use significant financial resources for the employment of those who belonged to trade unions like for examle in the European Union.

A different point of view says that government legislation concerning the labour market may be applied more effectively in an authoritarian system than in a democratic one. The authoritarian regimes often make use of individual interests of given circles. In most democratic countries there is no broad enough basis that would allow to use labour market policy for gaining the support from pressure groups, the urbanised labour marked elite included. The major difference between authoritarian and democratic regimes lies in the level of the outside influence. In a well functioning democracy, the outside opinions are also taken into account and there occur some limitations which come from the outside, which restricts the achievements of given groups of interest. In a dictatorship, a government cares only that those groups are not too strong. 
There is, however, a number of democracies among the industrialised countries where an effective labour market exists (Banerji and Ghanem, 1997). There is also a number of democracies with effective labour market policy among the developing countries (Banerji and Ghanem, 1997). Similarly, in the countries in which the transformation from the authoritarian regime towards a democracy is taking place, avoiding unfavourable phenomena on a labour market is often a priority. For example, the Chilean government moved towards democracy and to free trade unions without home income growth. The end of oppression in South Korea, in 1987, started the partnership relations in full of conflicts industry (Banerji and Ghanem, 1997).

It is worth considering which of the two points of view presented above should be given support, that is, which of them is the proper one. The analysis of that problem may be based on the Grossman and Helpman model (Grossman and Helpman, 1994). This model describes economic development on the basis of two sectors - urbanised, regulated processing sector, and rural, unregulated agricultural sector. The protection of the labour market, especially of minimum wages, is usually applied in order to bring the benefits for the employees of the regulated sector, since the sector of unregulated employees does not come under the legislation concerning the labour market.

The sector of regulated employees, and also the owners, demand from the government that it leads an economic policy that is favourable to them. The employed demand high minimum wages, while capitalists demand high profits. Both groups demand the restrictions on the degree of economy openness. In a closed economy, higher market minimum wages and higher profits are usually connected with higher prices for home consumers, and this is not easy when those consumers are free to buy the substitutes in form of imported goods. Thus, incomes in an economy may be created by protection and later divided among the employees of the regulated sector and the capitalists, although sometimes the government itself takes a part of those incomes (Banerji and Ghanem, 1997).

A government conducting an economic policy takes into account a number of factors. Firstly, it has to decide the degree of obtaining the resources, that is, how much from those resources it wants to obtain. Hence the importance of investments and of future economic growth, and also of defining the possibilities for keeping the power it is currently holding. Secondly, the government should define the scale of support from each of the pressure groups that can influence the situation. The position and importance of each group for the development of political processes should be considered. For example, in the country where the regulated labour market is divided, and politically weak, only the capitalists may have a deciding voice in political processes. And the contrary also happens - in the societies where the labour market is organised, it may play the important role in mobilising voters.

How can we recognise the type of power, the type of rule? First of all, we should investigate what level of resources a given government is going to achieve. If an authoritarian government is more or less corrupted than a democratic one, it will be creating the income, to a bigger or lesser degree, through protectionism. It will also appropriate some part of that income. Secondly, a given type of government may remain under the influence of different pressure groups. If an authoritarian government is trying, to some extent, to subordinate special pressure groups including the regulated labour sector, it will be, to some extent, generating incomes through protection and it will be turning over some part of them to those special pressure groups.

\subsection{Level of Protectionistic Pressures}

The above arguments show that the policy is defined by political factors (including the type of the government and the burdens resulting from obligations towards employees and capitalists), and by economical factors (wages, prices, the structure of production and consumption). On the basis of the present discussion, we can present two equations, one pertaining to the level of protection, and the second pertaining to the national economy and deformation of wages.

$$
\begin{aligned}
& \text { 1) } \pi=f(e, 1, k, R) \\
& \text { 2) } \varphi=f_{1}(\pi, e, 1, k, R) \text {, }
\end{aligned}
$$

The level of protection $(\pi)$ depends on the economic parameters (e), a relative political importance of urbanised employees and capitalists ( 1 and k, respectively), and on the type of the government (R). Deformation of wages is, on the other hand, the function of $\pi$ and of $\mathrm{e}, \mathrm{l}, \mathrm{k}$ and $\mathrm{R}$. In case of a small economy, economic parameters that can influence $\pi$ and $\varphi$ include flexible consumer and producer prices, demand flexibility, wages and the demand for labour force, and also the price of goods on an international market.

One can expect, a priori, that the growth of $\pi$ is dependant on 1 and $\mathrm{k}$. If interest groups become stronger, the pressure to form incomes based on protectionism may become stronger. The influence of R, that is, the influence of a political authoritarianism on the level of protectionism, that is, $\pi$, depends on the fact whether the opinion, that the level of protectionism depends on the effects of democratisation, is correct. It is also thought that the increase of the deformation of wages depends on $\pi$ and 1 , while its decrease depends on $\mathrm{k}$. As long as the incomes are obtained from trade protections, those incomes can be handed over to urbanised employees. An important problem in case of urbanised labour force as an interest group with growing strength is the fact that urbanised employees may gain a big share in the division of incomes 
but the growth of political importance of the capitalists may cause that the shared incomes, handed over to the labour force in regulated sectors of economy will become smaller (Banerji and Ghanem, 1997).

There is no doubt that it is easier for wealthy rather than poor societies to choose democracy (Helliwel, 1992). Since those wealthier societies at the same time have a tendency to a bigger openness, the direction of cause-result events may run from the openness of society to the political system, and not, as was suggested earlier, in the opposite direction. The research showed also that the level of education plays an important role in this respect. The countries with a higher level of education of labour force are more open.

On the basis of the earlier considerations, one can come to the conclusion that authoritarian systems have a tendency towards a broader application of protectionism than democratic systems, and that, in turn, the trade restrictions accompany significant deformations of wages on the labour market. This opinion may be justified on the basis of the observations of the situation in a number of countries.

Freedom of association is one of the elements of good management and the necessary condition for development. The authoritarian governments do not respect, however, the freedom of association, which is connected with the policy of trade restrictions and with the deformations on the labour markets. One cannot state, however, that improper or ineffective policy on the labour market belonged exclusively to authoritarian regimes or that authoritarianism automatically generates this kind of policy. There is a number of examples of authoritarian countries which do not conduct policies of that kind. The works of such authors as Fields or Freeman show that the repressions against the labour force are not necessary, if one wants to achieve a required economic growth (Fields, 1994; see also Freeman, 1993).

Finally, it should be pointed out that there exists a close relation between democracy and an economic growth, There are well known examples of open societies that stimulate the economic growth. This is true mainly in case of highly developed and strongly urbanised countries. In the countries with a developed democracy, the pressure groups have a bigger opportunity for acting. The research shows that the presence of trade unions helps to accelerate the economic reforms (Devarajan, Ghanem, Thierfelder, 1997). The benefits resulting from liberalisation of the international trade are bigger when the trade unions exist in the sector of the economy under protection. The growth of import abilities leads to the decrease of wage pressures, and when the trade unions agree to that, such a situation allows for a better allocation of labour force in the economy. This is true both in the case of active and passive trade unions, although the effects are better in case of active trade unions.

The trade unions active on an urbanised labour market had a significant influence on the decisions of governments, in the course of multilateral trade negotiations within WTO. It was especially evident in the negotiations on lowering customs duties and non-tariff measures in steel, shipbuilding, textile and clothing industries, and in coal mining. In the so-called "sensitive" industries, which, for example, in the European Union were under special trade protection, the position of trade unions was very strong.

\subsection{Food Producers Pressures}

The biggest conflicts between the United States and the European Union within WTO were caused by agricultural problems also during the Doha Round. The governments of the two economic powers were in many times under a very strong pressure of food producers, who had problems with the sale of agricultural products surpluses in the situation of the shrinking world market and lower prices.

The problem of liberalisation of agricultural products trading is linked to the problem of subsidies application. According to the WTO decisions (art. XVI), exports of the agricultural products, as so-called basic goods, can be subsidised, if this fact does not interfere with the economic interests of other participants of the agreement. Actually, subsidising exports of agricultural products may have many different forms, starting with a direct subsidy, through variable compensatory fees, and finally through various forms of government guarantees and preferential credits. In the ministers declaration we read only about a better discipline among the members of WTO. The total prohibition of subsidies would be the simplest course, but it does not seem to be realistic my be after 2013.

In an effort to limit the EU budget expense for subsidising agricultural products, it was decided, among other things, that in case of fats, the money will be transferred from the processing sector to the production sector. Instead of compensating the industry for higher costs of purchasing more expensive, local raw materials (the prices paid to the growers of rape or sunflower in the EU are much higher than the world prices), it was decided that subsidies would go directly to farmers, and the size of farms was to be the basis for calculations. At the same time, the Union authorities disclosed that they will be trying to reduce gradually those expenses by reducing guaranteed prices.

This reform was the first in which the attempt was made to eliminate the structural surpluses, the surpluses which had been disorganising the EU agricultural market and the international trade for many years. It is worth pointing out here that the direct result of announced changes in the agricultural policy of the EU may not be favourable in the abroad. The simplest form of compensation for farmers are usually the restrictions for the suppliers from abroad. The agricultural 
lobby in France is especially active in this area. As a result of its activity and the pressure exerted on the government the agricultural goods from abroad have been successfully blocked from the EU market. The position taken by that agricultural lobby influenced also the position of the EU representatives in the debates on the agricultural questions during the multilateral trade negotiations also in the framework of the Doha Round.

In spite of the trade conflicts, most clearly visible in the USA - the EU relations, all the countries participating in the international trade were interested in the successful of the international trade negotiations. The reduction or the elimination of trade restrictions stimulates significantly the growth of the world trade exchange, while the foreign trade, in turn, is an important factor of the economic growth of individual countries.

\subsection{International Trade Liberalisation and Environmental Protection}

The tendencies to liberalise the international trade often stand in clear conflict with the protection of the natural environment which, during the intensification of production, found itself in the centre of attention. The process of pollution was one of the negative results of scientific-technological revolution. Many countries introduced special legal regulations in order to protect the environment against pollution. Ecological organisations of different types were established, and also the pressure groups, especially in industrialised countries, interested in the use of trade restrictions by governments for protection of the environment.

The pressure groups acting for natural environment protection see the trade policy in two aspects: as the way of improvement the standards of environmental protection in individual countries and over their borders, and as the instrument for persuading those countries to sign the international agreements on environmental protection. The imports restrictions against the producers coming from the countries with low standards of environmental protection may lead to the improvement of production standards by the local companies resulting from fighting with low competitiveness, and from the attempts to compete with foreign firms (Anderson, 1997).

The application, in trade policy, of discriminating means in relation to the environment, which happened in the countries of western Europe, is in accordance with the article XX of WTO, and it testifies to the fact that trade barriers are used for the protection of the environment. Thus, the activities related to environmental protection are in conflict with the tendencies leading to international trade liberalisation, and with higher investments. From the theoretical point of view, we cannot say that trade liberalisation may help the environmental protection, especially when serious steps have to be taken in order to protect this environment against further degradation (Chichilnisky, 1994; see also Copland and Taylor, 1995; Corden, 1996). On the other hand, when some government find itself in a difficult situation, the trade reforms will be much more advantageous for that government than the actions in the environmental protection area (Bhagwati and Srinivisan, 1996). That is why the pressure groups connected with the environmental protection are against the international trade liberalisation.

The actions of those groups on WTO forum, and their regional activity against the reduction of trade barriers, have three reasons: 1) free trade means the growth of production and income, which, in turn, leads to the degradation of the environment, 2) free trade and growing investments cause the growth of transport activity and encourage companies to transfer the production to the countries with low ecological standards, which from the environmental point of view is wrong, 3) freedom for foreign investments discourage local companies to develop the technologies favourable for environmental protection (Anderson, 1997).The question of reaching some form of an agreement between the problems of international trade liberalisation and the protection of natural environment especially in the context of the sustainable development became an important task for the WTO. The program of WTO activities included:

- the relations between the means used in trade and in environmental protection

- the relations between multilateral trade systems and the environmental protection means, applied for protection of the environment

- the influence of the effects of environmental protection on the liberalisation of international trade

- the relations between the mechanisms leading to compromises within WTO and within the multilateral agreements on environmental protection (Martin and Winters, 1995).

Reaching the effective agreements on the international trade liberalisation and on environmental protection in the light of sustaiable development is considered to be both very difficult and very delicate question. The problems of environmental protection have become most important issues. Therefore, it is evident that the international market has to take them into account. In the context of the sustainable development, the key problem is to make a proper choice: is the introduction of restrictions on international trade the best solution, or will the benefits from environmental protection (as applied by a multilateral trade system) be higher than the costs?

It is necessary also to emphasis that if the rules of international trade are clear - and if they are perceived to be supportive of important environmental values - then their legitimacy will be much greater. Over the long term, public support for the 
WTO depends on a perception that it is balanced and fair (Esty, 1998). Efforts to address the issues identified above could greatly enhance the WTO's reputation. Competing trade and environmental principles could best be balanced through creation of an interpretive statement that focuses on how the "exceptions" spelled out in Article XX would be implemented, rather than through full-blown renegotiation of the environmental elements of the trading system (Esty, 2000).

Finding ways to adress the environmental issues that inescapably arise in the context of deeper economic integration and tendency to the sustainable development must be seen as an important trade policy priority, as a matter of WTO commitment to undergirding the trade regime with sound economic theory, and as a matter of political necessity. Building a trading system that is more sensitive to pollution control and natural resources management issues is mandated by the growing degree to which these realms intersect with trade and environmental policies mutually reinforcing are also advisable to the extent that the presence of trade rules that internalize externalities will prove to be more economically efficient over time. Institutionalizing the links from the trade regime to environmental actors and other elements of civil society will also pay dividends. A culture of opennes within the WTO is likely to generate policies that the public accepts and that therefore become more useful and durable (Esty, 2000).

\section{6 Bilateral Tendencies in Contemporary Foreign Trade Policy}

The tendencies in international trade development can create changes in domestic markets, placing pressure on political actors to obtain aid from the government. There are also the groups which want to coordinate activities and change foreign trade policy. European Commission provide the justification for protection of the internal single market to response to global competition. It is important underline that essentially, the government appears to supply protection for affected parties; yet, the overall impact on consumers, producers, and foreign competition is neglible (Thies and Porche, 2007). Significant government ownership of the productive resources of a country has a negative effect on trade liberalisation, while fragmentation of decision-making authority, expressed as fragmentation within the government and pluralism in society, has a positive impact on the libaralization of trade policy (Kennedy, 2007).

In the area of foreign-policy analysis has focused on "three i's": interest groups, international structure, and ideas (Kennedy, 2007). In the interests groups literature, government policy is viewed as the outcome of competition between groups for trade policies that benefit their industry (Nau, 1989; Milner, 1995; Milner and Yoffie, 1989; Schattschneider, 1935). International structure suggests that freer trade was a reflection on U.S. interests and its hegemonic status after World War II, while a decline in free trade is a reflection of the U.S.'s hegemonic decline (Krasner, 1976). The literature on ideas suggests that policy belifs are reflected in laws and institutions. These laws and institutions, in turn, carry a type of interia that continues to influence policy outcomes long after changes in international and internal structure would predict policy change (Goldstein, 1989; Goldstein, 1995). In contrast to these explanations government interests in the economy and in maintaining stability also play a large role in trade policy (Kennedy, 2007 ).

At one end, a multilateral forum like World Trade Organisation (WTO) with near universal membership offers maximization of gains from trade and reduced transaction costs. However, a single state cannot expect to have much control over trade partners or liberalistion agendas at the multilateral level. At the other end, a bilateral FTA often yields very small gains from trade and usually increases transaction costs by producing idiosyncratic sets of rules. But at the same time, a large state, can acquire a high level of control in terms of partners, issues and agenda selection, and sectoral exclusions or inclusions based on domestic political needs (Pekkanen, Solis, and Katada, 2007). One can contend that industrialized of aggregate economic gains in the interest of national welfare (largest in multilateral forums) or seeking control over rules in line with political interests (greatest in bilateral forums).

It is important underline that the liberalizing rules on agriculture, and other less competitive sectors, are no longer an acceptable political price for the economic gains bundled across sectors. Yet, this sort of vague statement fosters uncertainty for domestic actors at home in uncompetitive sectors like agriculture and in several cases like for exemple in European Union and Japan trade officials need to show that they have more concrete control for political reasons-an element more credible in a bilateral setting than a multilateral one (Pekkanen, Solis, and Katada, 2007). This situation may also indicat the back from globalisation to the mercantilist tendencies in the foreign trade policy.

\section{Conclusion}

The foreign trade policy plays a key role in the maintenance of both economic and political liberalisation. The prominence of rent seeking in a country can have far-reaching implication for its economic development. Especially in underdeveloped or transitional countries, rent seeking takes scarce resource out of productive areas in the economy, using them to promote and/or perpetuate further rents.

Structural and micro-political economy analyses of foreign trade policy in the context of the sustainable development have missed the impact of changing ideas about protectionism and relatively unchanging institutions designed to handle domestic producer complaints. The political consensus on the supply of foreign trade policy and protectionism has 
changed over time. In the economic depression tariffs revenues and protectionism played important roles in the politics of political parties. At the same time in the market economy even during the economic depression one can observe a little support for liberal foreign trade policy. It is necessary to emphasize that in the foreign trade policy there are not pure liberalism and pure protectionism. In the high economic growth there are tendencies to liberalism in foreign trade policy and in the economic crisis there are tendencies to protectionism.

Finding ways to address the environmental issues that inescapably arise in the context of deeper economic integration and tendency to the sustainable development must be seen as an important trade policy priority, as a matter of WTO commitment to undergirding the trade regime with sound economic theory, and as a matter of political necessity. Building a trading system that is more sensitive to pollution control and natural resources management issues is mandated by the growing degree to which these realms intersect with trade and environmental policies mutually reinforcing are also advisable to the extent that the presence of trade rules.

\section{References}

Alt, J. E., \& Gilligan, M. J. (1994). The Political Economy of Trading States. Journal of Political Philosophy, 2, 165-192.

Alt, J. E., Frieden, J., Gilligan, M. J., Rodrik, D., \& Rogowski, R. (1996). The Political Economy of International Trade: Enduring Puzzles and an Agenda for Inquiry, Comparative Political Studies, 29, 689-717.

Anderson, K. (1995). Lobbying Incentives and the Pattern of Protection in Rich and Poor Countries. Economic Development and Cultural Change, 43, 401-423.

Anderson, K. (1997). Environmental Standards and International Trade, In: "Annual World Bank Conference an Development Economics 1996, M. Bruno and B. Pleskovic, (eds), The World Bank, Washington D.C., 319.

Aslund, A. (2002). Building Capitalism: The Transformation of the Former Soviet Bloc. Cambridge: Cambridge University Press.

Banerji, A., \& Ghanem H. (1997). Does the Type of Political Regime Matter for Trade and Labour Market Policies?, The World Bank Economic Review, 11(1), 73.

Bhagwati, J. N., \& Srinivisan, T. N. (1996). Trade and the Environment: Does Environmental Diversity Detract from the Case for Free Trade? In: J. N. Bhagwati and R. E. Hudec, (Eds), Fair Trade and Harmonization: Prerequisites for Free Trade?, Cambridge, Mass.: M IT Press.

Busch, M. L., \& Reinhard E. (1999). Industrial Locations and Protection: The Political and Economic Geography of U.S. Nontariff Barriers, American Journal of Political Science, 43, 1028-1050.

Busch, Marc L., \& Reinhard E. (2000). Geography, International Trade, and Political Mobilization in U.S. Industries. American Journal of Political Science, 44, 703-719.

Caughlin, C. C., Chrystal K. A., \& Wood, G. E. (1995). Protectionist Trade Policies: A Survey of Theory, Evidence, and Rationale. In: Frieden J.A. and Lake D. A. (Eds). International Political Economy: Perspectives on Global Power and Wealth. $3^{\text {rd }}$ edition, New York: St Martin,s Press.

Chichilnisky, G. (1994). North South Trade and the Global Environment, American Economic Review, 84(4). 831-874.

Cohn, T. H. (2000). Global Political Economy. Theory and Practice, New York.

Coleman, W. D. (1998). From Protected Development to Market Liberalism. Paradigm Change in Agriculture. Journal of European Public Policy, 5, 632-651.

Copland, B. R., \& Taylor, M. S. (1995). Trade and Transboundary Pollution, American Economic Review, 85(4). 713-737.

Corden W.M. (1996). The Environment and Trade Policy, In: Corden W. M. (Eds), Trade Policy and Economic Welfare, Oxford: Clarendon Press.

Devarajan, S., Ghanem, H., \& Thierfelder, K. (1997): Economic Reform and Labor Unions: A General Equilibrium Analysis Applied to Bangladesh and Indonesia. The World Bank Economic Review, 11(1), 145-170.

Esty, D. C. (1998). NGOs at the World Trade Organisation: Cooperation, Competition, or Exclusion, Journal of International Economic Law, 1(1), 123.

Esty, D. C.(2000). Environment and the Trading System: Picking up the Post-Seattle Pieces, In: Schott J.J. (Eds)., The WTO after Seattle, Washington, DC. Institut for International Economics, 250-251.

Fields, G. (1994). Changing Labor Market Conditions and Economic Development in Hong Kong, Singapore and Taiwan, Cornell University, Ithaca, New York, Processed. 
Freeman, R. (1993). Does Suppression of Labor Contribute to Economic Success? Labor Relations and Markets in East Asia. Harvard University, Cambridge, Mass. and London School of Economics, London. Processed.

Frey, B. S., Pommerehne, W., Schneider, F., \& Gilbert, G. (1984). Consensus and Disconsensus among Economists: An Empirical Inquiry. American Economic Review, 74, 986-994.

Frey, B. S. (1984). The public Choice View of International Political Economy. International Organization, 38, $199-223$.

Frieden, J. (1991): Debt, Development and Democracy. Princeton: Princeton University Press.

Frieden, J., \& Rogowski R. (1996). The Impact of International Economy on National Policies: An Intellectual Overview. In: Keohane R.O. and Milner H.V. (Eds) Internationalization and Domestic Politics, Cambridge: Cambridge University Press.

Goldstein, J. (1989). The Impact of Ideas on Trade Policy: The Origins of U.S. Agricultural and Manufacturing Policies., International Organization, 43, 31-71.

Goldstein, J. (1995). Ideas, Institutions and American Trade Policy. In: J. A. Frieden and D. A.Lake (Eds), International Political Economy: Perspectives on Global Power and Wealth. $3^{\text {rd }}$ edition, New York: St Martin,s Press.

Grossman, G., \& Helpman, E. (1994). Protection for Sale, American Economic Review, 84(4).

Helliwel, J. F. (1992). Empirical Linkages between Democracy and Economic Growth, Working Paper 4066. National Bureau of Economic Research, Cambridge, Mass. Processed

Kennedy, R. (2007). Fragments of Economic Accountability and Trade Policy. Foreign Policy Analysis, 3, $145-169$.

Kitschelt, H., Mansfeldova, Z., Markowski, R., \& Toka, G., (1999). Post-Communist Party System: Competition, Representation, and Inter-Party Cooperation. Cambridge: Cambridge University Press.

Krasner, S. D. (1976). State Power and the Structure of International Trade. World Politics, 28, 317-347.

Magee, S. P., Brock, W. A., \& Young, L. (1989). Black Hole Tariffs and Endogenous Policy Theory Political Economy in Genaral Equilibrium. Cambridge: Cambridge University Press.

Martin, W., \& Winters, L. A. (1995). The Uruguay Round: Widening and Deepening the World Trading Systems, World Bank Policy Research, Bulletin, 6(5).

McGillivary, F. (1997). Party Discipline as a Determinant of the Endogenous Formation of Tariffs. American Journal of Political Science, 41, 584-607.

Milner, H. V. (1995): Resisting the Protectionism Temtation: Industry and the Making of Trade Policy in France and the United States during the 1970s. In: J. A. Frieden and D. A.Lake (Eds), International Political Economy: Perspectives on Global Power and Wealth. $3^{\text {rd }}$ edition, New York: St Martin,s Press.

Milner, H. V., \& Yoffie D. B. (1989). Between Free Trade and Protectionism: Strategic Trade Policy and a Theory of Corporate Trade Demands. International Organization, 43, 239-272.

Multilateral Agreement on Investment and Related Initiatives. (2006): Global Policy Forum (GFP). Available at http://www.globalpolicy.org. (Accessed June 13).

Murphy, K. M., Shleifer, A., \& Vishny R. W. (1993). Why is Rent-Seeking so Costly to Growth? The American Economic Review", 83, 409-414.

Nau, H. R. (1989). Domestic Trade Politics and the Uruguay Round: An Overview. In: Nau, H.R. (Eds) Domestic Trade Politics and the Uruguay Round. New York: Columbia University Press.

Nelson, D. (1988). Endogenous Tariff Theory: A Critical Review. American Journal of Political Science 32. $796-837$.

Nielson, D. L. (2003). Supplying Trade Reform: Political Institutions and Liberalization in Middle-Income Presidetial Democracies. American Journal of Political Science, 47, 470-491.

Olson, M. (1985). Space, Agriculture and Organization. American Journal of Agricultural Economics, 67, $928-937$.

Olson, M. (1986). The Exploitation and Subsidization of Agriculture in Developing and Developed Countries. In: Maunder, A., \& Renborg, U. (Eds). Agriculture in a Turbulent World Economy. Gower, U. K. Aldershot.

Pekkanen S. M., Solis, M., \& Katada, S. N. (2007). Trading Gains for Contro: International Forums and Japanese Economic Diplomacy. International Studies Quarterly, 51, 945-970.

Rodrik, D. (1995). Political Economy of Trade Policy. In: Grossman, G. and Rogoff, K. (Eds). Handbook of International Economics, 3, Amsterdam: Elsevier Science. 
Rogowski, R. (1987). Political Cleavages and Changig Exposures to Trade. American Political Science Review, 81, 1121-1137.

Rogowski, R. (1987). Trade and the Variety of Democratic Institutions. International Organization, 41, $203-222$.

Rogowski, R. (1989). Commerce and Coalitions. Princeton, NJ: Princeton University Press.

Schattschneider E. E. (1935). Politics, Pressure and the Tariff. New York: Prentice Hall.

Sheingate, A. D. (2001). The Rise of Agricultureal Welfare State: Institutions and Interests Group Power in the United States, France, and Japan. Princeton, NJ: Princeton University Press.

Thies, C. G., \& Porche, S. (2007). Crawfish Tails: A Curious Tale of Foreign Trade Policy Making. Foreign Policy Analysis, 3, 171-187.

\section{(cc) $\mathrm{EY}$}

This work is licensed under a Creative Commons Attribution 3.0 License. 